\title{
The Impact of Natural Disaster on Mental Health of Victims Lives: Systematic Review
}

\author{
${ }^{1}$ Kristia Novia , ${ }^{2}$ Tita Hariyanti, ${ }^{3}$ Laily Yuliatun \\ ${ }^{1}$ Master Program of Nursing, Faculty of Medicine Brawijaya University, Indonesia \\ ${ }^{2} 3$ Departemen of Master in Management Hospital, Faculty of Medicine Brawijaya \\ University, Indonesia \\ Email: kristia15novia@gmail.com
}

\begin{abstract}
Natural disasters are still a matter of the world until today. The events pose not only physical impact but also psychological impacts that leave deep sorrow and fear. The survivors of the disaster felt they were at a very unsettled condition, felt very fearful, felt agitated for uncertain circumstances, and became very easily panicked until they could experience anxiety, depression, and post-traumatic stress disorder (PTSD). This systematic review aims to identify the impact-effects often posed by natural disasters on the soul health of survivors. Data searching is done on the Proquest, Pubmed, Science Direct, Sage, and Scopus databases that were converged in the 2013 to 2019 ranges. The psychological impact experienced by the victims after natural disaster events are depression, post-traumatic stress disorder (PTSD), fear, suicide experiments, and other mental health disorders such as mood changes and a loss of interest in an activity. Natural disasters can hurt the mental health of the victims. If the psychological problems that occur to the victims are not immediately addressed, the victims will fall on more mental severe disorder conditions.
\end{abstract}

Keyword: Impact, Natural Disaster, Mental Health, Victims

\section{A. INTRODUCTION}

Natural disasters are still a problem in the world today. According to Act Number.24 year, natural disasters are a series of events caused by natural phenomena, such as volcanic eruptions, floods, droughts, landslides, and earthquakes. These events can cause such health crises, the collapse of health care, infectious disease, stress/mental disorders, lack of clean water, environmental sanitation problems, livelihood issues, injuries to fatalities ${ }^{1}$. The disasters caused increased attention to health issues that caused the global permanent and interfered with daily activities. The purpose of this paper is to summarize systematically the findings related to the impact of natural disasters on the mental health of disaster victims. Natural disasters make victims face complex problems, not only physical problems but also psychological problems such as feeling depressed, moody, depression, and trauma-natural catastrophic events resulting in impaired balance a person's mental condition that can lead to severe stress ${ }^{2}$. According to Nurrachaman (2007), three factors influence disaster victims under stress: natural disasters and frightening and life-threatening, the loss of a loved one, and the loss of 
property and livelihood to make the victim struggling to meet the basic needs of life. Stress experienced by victims of natural disasters is the impact of traumatic experiences. Psychological trauma is a condition where a person experiencing physical or mental disorders as a result of events/experiences are pretty awful and make them helpless. Injury is also often associated with the condition of people who battered by bitter experiences that happened to them. The impact of the maladaptive stress will cause a reaction in individuals who have difficulty finding clean water sanitation problems, livelihood issues, and injuries to fatalities ${ }^{1}$. The disasters caused increased attention to health issues that caused the global permanent and interfered with daily activities. The purpose of this paper is to summarize systematically the findings related to the impact of natural disasters on the mental health of disaster victims.

\section{B. DISCUSSION}

\section{Literature search strategy}

To identify all relevant publications, searches conducted on databases of Proquest, Pubmed, Science Direct, Sage and Scopus The keywords used in the search is the "impact" or "effect," "natural disaster," "mental health" and "victims" with restrictions only articles in English. The guidelines used in specifying the number of items in a review were determined using the PRISMA method. Criteria for inclusion in this study is a review article on 1) experience, 2) mental health issues disaster victims. The selected item is an article reviewing at least one of the two criteria. While exclusion criteria in this study were 1) to discuss items that are not about the experience and mental health concerns to victims, 2) duplicate articles. The searching process based on the PRISMA flow and can be seen in (Fig.1)

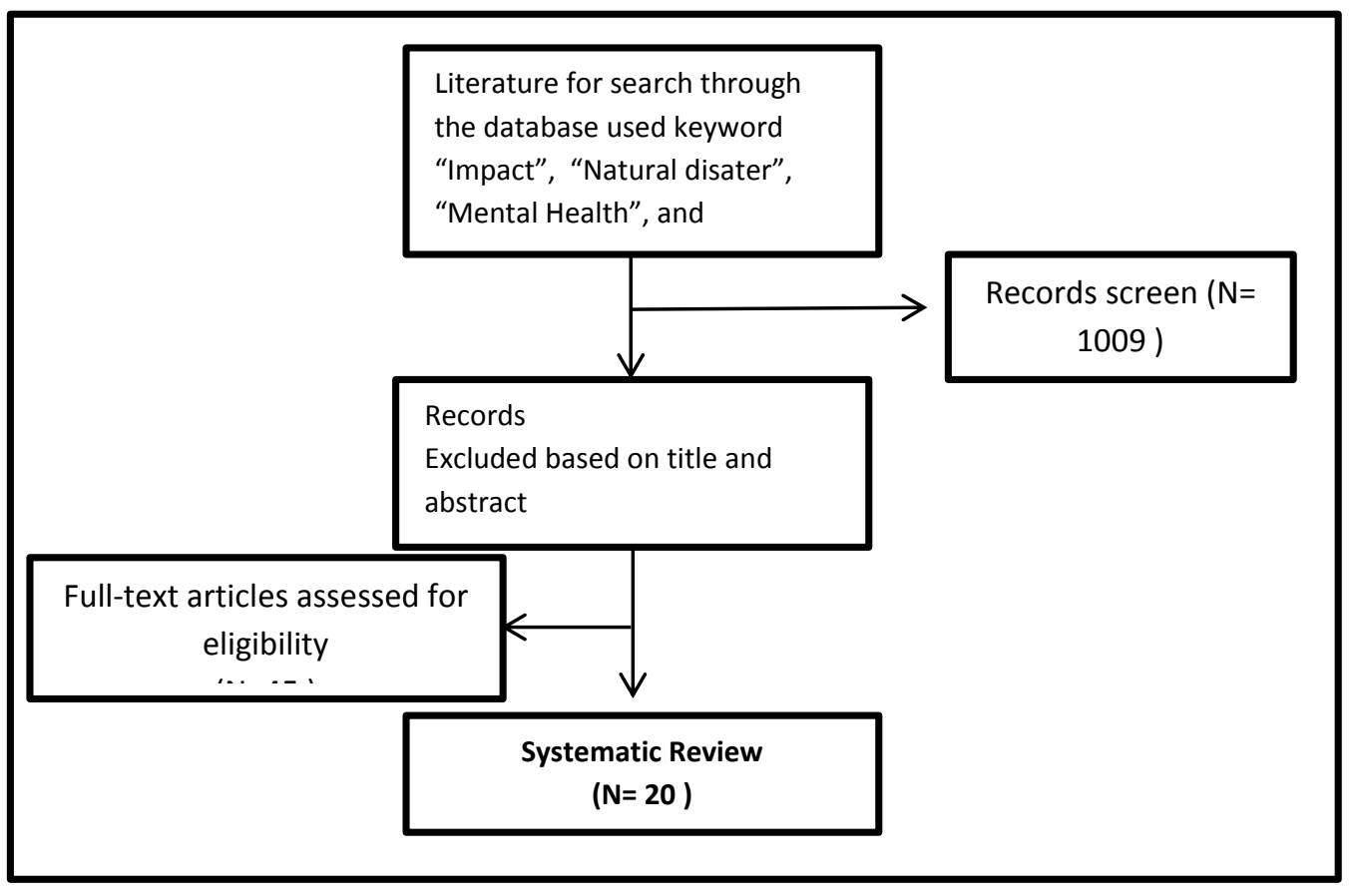


Tabel 1. Summary of articles

\begin{tabular}{|c|c|c|c|c|c|}
\hline No. & Title & Author/year & Objectives & Methods & Result \\
\hline 1. & $\begin{array}{l}\text { Criticism } \\
\text { by } \\
\text { communit } \\
\text { y people } \\
\text { and poor } \\
\text { workplace } \\
\text { communic } \\
\text { ation as } \\
\text { risk factors } \\
\text { for the } \\
\text { mental } \\
\text { health of } \\
\text { local } \\
\text { welfare } \\
\text { workers } \\
\text { after the } \\
\text { Great East } \\
\text { Japan } \\
\text { Earthquak } \\
\text { e: A cross- } \\
\text { sectional } \\
\text { study }\end{array}$ & $\begin{array}{l}\text { Author: } \\
\text { Ueda et al } \\
\text { /2017 }\end{array}$ & $\begin{array}{l}\text { 1. To determine mental } \\
\text { health disorders } \\
\text { experienced by social } \\
\text { welfare workers (Shakyo) } \\
\text { such as depression, } \\
\text { PTSD, and other } \\
\text { psychological distress } \\
\text { after the earthquake. } \\
\text { To determine the factors } \\
\text { that affect mental health } \\
\text { caseworkers (Shakyo). }\end{array}$ & $\begin{array}{l}\text { Multivariate } \\
\text { logistic } \\
\text { regression } \\
\text { Descriptive } \\
\text { analysis with } \\
\text { a non- } \\
\text { experimental } \\
\text { approach }\end{array}$ & $\begin{array}{l}\text { The results of this } \\
\text { study found as many } \\
\text { as } 819 \text { ( } 81.3 \% \text { )Local } \\
\text { social welfare } \\
\text { workers (SHAKYO) } \\
\text { the possibility to } \\
\text { experience a mental } \\
\text { health problem such } \\
\text { as depression, post- } \\
\text { traumatic stress } \\
\text { disorder (PTSD), } \\
\text { and psychological } \\
\text { pressure after an } \\
\text { earthquake. Social } \\
\text { factors associated } \\
\text { with work, } \\
\text { including criticism } \\
\text { by the public and the } \\
\text { lack of } \\
\text { communication in } \\
\text { the workplace, are } \\
\text { associated with the } \\
\text { risk of mental health } \\
\text { problems to social } \\
\text { workers (SHAKYO) } \\
\text { after an earthquake. }\end{array}$ \\
\hline 2. & $\begin{array}{l}\text { Assessing } \\
\text { the Mental } \\
\text { Health }\end{array}$ & $\begin{array}{l}\text { Author:Li } \\
\text { eber/ } \\
2017\end{array}$ & $\begin{array}{l}\text { 1. Assess the mental health } \\
\text { of children of primary } \\
\text { and secondary schools }\end{array}$ & $\begin{array}{l}\text { Multivar } \\
\text { iate } \\
\text { logistic }\end{array}$ & $\begin{array}{l}\text { The results showed } \\
\text { that children } \\
\text { traumatized in the }\end{array}$ \\
\hline
\end{tabular}

http://iisoc.goacademica.com 


\begin{tabular}{|c|c|c|c|c|c|}
\hline & $\begin{array}{l}\text { Impact of } \\
\text { the } 2011 \\
\text { Great } \\
\text { Japan } \\
\text { Earthquak } \\
\text { e, } \\
\text { Tsunami, } \\
\text { and } \\
\text { Radiation } \\
\text { Disaster on } \\
\text { Elementar } \\
\text { y and } \\
\text { Middle } \\
\text { School } \\
\text { Children } \\
\text { in the } \\
\text { Fukushim } \\
\text { a } \\
\text { Prefecture } \\
\text { of Japan }\end{array}$ & & $\begin{array}{l}\text { living in the Fukushima } \\
\text { prefecture of Japan. } \\
\text { 2. identify risk and } \\
\text { protective factors } \\
\text { associated with mental } \\
\text { health scores of children }\end{array}$ & $\begin{array}{l}\text { regressio } \\
\mathrm{n} \\
\text { Descript } \\
\text { ive } \\
\text { analysis } \\
\text { with a } \\
\text { non- } \\
\text { experim } \\
\text { ental } \\
\text { approac } \\
\mathrm{h}\end{array}$ & $\begin{array}{l}\text { past are more prone } \\
\text { to mental health } \\
\text { disorders. }\end{array}$ \\
\hline 3. & $\begin{array}{l}\text { The } \\
\text { Impact of } \\
\text { Drought } \\
\text { on Mental } \\
\text { Health in } \\
\text { Rural and } \\
\text { Regional } \\
\text { Australia }\end{array}$ & $\begin{array}{l}\text { Author: } \\
\text { Edwards } \\
\text { et al./ } \\
2015\end{array}$ & $\begin{array}{l}\text { It was knowing the } \\
\text { impact of drought in } \\
\text { Australia on the mental } \\
\text { health of people who } \\
\text { experience dryness, } \\
\text { especially farmers. }\end{array}$ & $\begin{array}{l}\text { Regressi } \\
\text { on } \\
\text { analysis }\end{array}$ & $\begin{array}{l}\text { The results of this } \\
\text { study showed } 15.7 \% \\
\text { of the farmers have a } \\
\text { mental health } \\
\text { problem is bigger } \\
\text { than the agricultural } \\
\text { workers in general } \\
(9.1 \%) \text {, working in } \\
\text { the field of non - } \\
\text { agriculture (8.9\%), } \\
\text { did not work } \\
(17.4 \%) \text {. }\end{array}$ \\
\hline
\end{tabular}

IJSOC $\odot 2020$

http://ijsoc.goacademica.com 


\begin{tabular}{|c|c|c|c|c|c|}
\hline 4. & $\begin{array}{l}\text { Mental } \\
\text { Health } \\
\text { Problems } \\
\text { following } \\
\text { the } 2005 \\
\text { Earthquak } \\
\text { e in } \\
\text { Kashmir: } \\
\text { Findings } \\
\text { of } \\
\text { Communit } \\
\text { y-Run } \\
\text { Clinics }\end{array}$ & $\begin{array}{l}\text { Author: } \\
\text { Chadda } \\
\text { et al., / } \\
2014\end{array}$ & $\begin{array}{l}\text { Knowing the impact of } \\
\text { earthquakes on mental } \\
\text { health in Kashmir }\end{array}$ & $\begin{array}{l}\text { Quantita } \\
\text { tive }\end{array}$ & $\begin{array}{l}\text { The results of this } \\
\text { study are as much as } \\
40 \% \text { of samples of } \\
\text { women, and } 30 \% \text { of } \\
\text { the sample of men } \\
\text { experience physical } \\
\text { complaints, around } \\
30 \% \text { of people } \\
\text { reported having a } \\
\text { sign - a sign of } \\
\text { depression such as } \\
\text { the inability in } \\
\text { feeling pleasure, loss } \\
\text { of interest in doing } \\
\text { daily activities - day, } \\
\text { and about } 10 \% \text { had } \\
\text { suicidal ideation } \\
\text { self. }\end{array}$ \\
\hline 5. & $\begin{array}{l}\text { Depressio } \\
\mathrm{n} \text { and its } \\
\text { risk factors } \\
\text { among } \\
\text { pregnant } \\
\text { women in } \\
\text { the } 2008 \\
\text { Sichuan } \\
\text { earthquak } \\
\text { e and non- } \\
\text { earthquak } \\
\text { e area } \\
\text { struck an }\end{array}$ & $\begin{array}{l}\text { Author: } \\
\text { Dong et } \\
\text { a., /l2013 }\end{array}$ & $\begin{array}{l}\text { 1. To assess whether there } \\
\text { is a negative impact on } \\
\text { the mental health of } \\
\text { pregnant women } \\
\text { generated by the Sichuan } \\
\text { earthquake occurrences } \\
\text { women after four years } \\
\text { 2. To identify risk factors } \\
\text { and symptoms of } \\
\text { depression among } \\
\text { pregnant women }\end{array}$ & $\begin{array}{l}\text { Descript } \\
\text { ive } \\
\text { analysis } \\
\text { with } \\
\text { logistic } \\
\text { regressio } \\
\mathrm{n} \\
\text { multivar } \\
\text { iate }\end{array}$ & $\begin{array}{l}\text { The results showed: } \\
\text { 1. } 35.4 \% \text { of pregnant } \\
\text { women in the } \\
\text { earthquake area } \\
\text { (Mianzhu) were } \\
\text { depressed and } 33.9 \% \\
\text { in the region } \\
\text { (Gaonbeidan) } \\
\text { 2. Prenatal depression } \\
\text { risk factors include } \\
\text { pregnancy pressure, } \\
\text { general social } \\
\text { support from their } \\
\text { husbands. }\end{array}$ \\
\hline
\end{tabular}

IJSOC $\odot 2020$

http://ijsoc.goacademica.com 


\begin{tabular}{|c|c|c|c|c|c|}
\hline & $\begin{array}{l}\text { area in } \\
\text { China. }\end{array}$ & & & & \\
\hline 6. & $\begin{array}{l}\text { Assessmen } \\
\mathrm{t} \text { of } \\
\text { prevalence } \\
\text { and } \\
\text { determina } \\
\text { nts of post- } \\
\text { traumatic } \\
\text { stress } \\
\text { disorder } \\
\text { and } \\
\text { depression } \\
\text { symptoms } \\
\text { in adults } \\
\text { survivors } \\
\text { of an } \\
\text { earthquak } \\
\text { e in Haiti } \\
\text { after } 30 \\
\text { months }\end{array}$ & $\begin{array}{l}\text { Author: } \\
\text { Cenat } \\
\text { and } \\
\text { Derivois/ } \\
2014\end{array}$ & $\begin{array}{l}\text { It was knowing the } \\
\text { impact of the earthquake } \\
\text { in adults two and a half } \\
\text { years later. Also, factors } \\
\text { predictive of PTSD and } \\
\text { depressive symptoms } \\
\text { were identified. }\end{array}$ & $\begin{array}{l}\text { Quantita } \\
\text { tive }\end{array}$ & $\begin{array}{l}\text { The results found } \\
\text { The prevalence rate } \\
\text { of PTSD and } \\
\text { depressive } \\
\text { symptoms was } \\
36.75 \% \text { (498 cases) } \\
\text { and } 25.98 \% \text { (352). } \\
\text { 2. The risk factors for } \\
\text { PTSD and } \\
\text { depressive the } \\
\text { symptoms are the } \\
\text { younger and older } \\
\text { age, female gender, } \\
\text { unemployment } \\
\text { status, and low } \\
\text { education levels. }\end{array}$ \\
\hline 7. & $\begin{array}{l}\text { Young } \\
\text { adults' fear } \\
\text { of } \\
\text { disasters: } \\
\text { A case } \\
\text { study of } \\
\text { residents } \\
\text { from } \\
\text { Turkey, } \\
\text { Serbia, and } \\
\text { Macedonia }\end{array}$ & $\begin{array}{l}\text { Cvetkovi } \\
\text { c/ } 2019\end{array}$ & $\begin{array}{l}\text { To know the fear of } \\
\text { natural disasters in adults } \\
\text { in Turkey, Serbia, and } \\
\text { Macedonia. }\end{array}$ & $\begin{array}{l}\text { Quantita } \\
\text { tive by } \\
\text { using } \\
\text { purposi } \\
\text { ve } \\
\text { samplin } \\
\text { g. }\end{array}$ & $\begin{array}{l}\text { The results showed } \\
\text { that. } \\
\text { 1. Almost all } \\
\text { participants feel fear } \\
\text { of all the disaster on } \\
\text { many levels. } \\
\text { 2. According to the } \\
\text { average percentage } \\
\text { of the three } \\
\text { countries, the }\end{array}$ \\
\hline
\end{tabular}




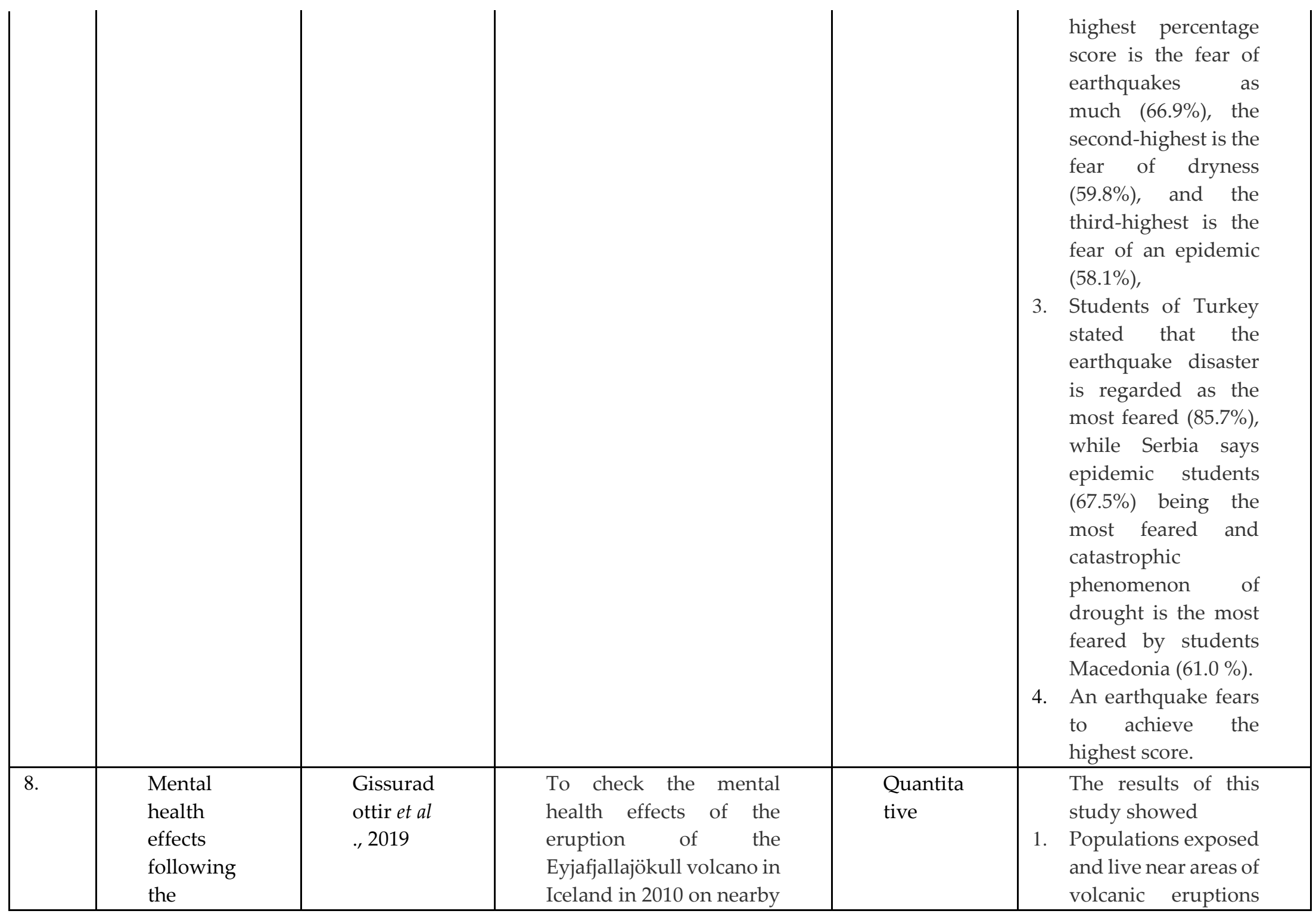

IJSOC $\odot 2020$

http://ijsoc.goacademica.com 


\begin{tabular}{|c|c|c|c|c|c|c|}
\hline & $\begin{array}{l}\text { eruption in } \\
\text { Eyjafjallajö } \\
\text { kull } \\
\text { volcano in } \\
\text { Iceland: A } \\
\text { population } \\
\text {-based } \\
\text { study }\end{array}$ & & $\begin{array}{l}\text { residents, the level of } \\
\text { exposure and experience. }\end{array}$ & & 2. & $\begin{array}{l}\text { more likely to have } \\
\text { mental health } \\
\text { problems than } \\
\text { people who do not } \\
\text { live and not exposed } \\
\text { to the volcanic } \\
\text { eruption. } \\
\text { People who directly } \\
\text { experience the } \\
\text { eruption are more } \\
\text { likely to suffer } \\
\text { symptoms of mental } \\
\text { disorder, the } \\
\text { symptoms of PTSD, } \\
\text { and stress. }\end{array}$ \\
\hline 9. & $\begin{array}{l}\text { Prevalence } \\
\text { and } \\
\text { predictors } \\
\text { of PTSD } \\
\text { and } \\
\text { depression } \\
\text { among } \\
\text { adolescent } \\
\text { Victims of } \\
\text { the } \\
\text { Summer } \\
2016 \\
\text { tornado in } \\
\text { Yancheng } \\
\text { City }\end{array}$ & $\begin{array}{l}\text { Xu et al./ } \\
2018\end{array}$ & $\begin{array}{l}\text { The level of prevalence of } \\
\text { the possibility of post- } \\
\text { traumatic stress disorder } \\
\text { (PTSD) and depression in } \\
\text { adolescents who } \\
\text { experienced a tornado } \\
\text { Yancheng 2016, } 3 \text { months } \\
\text { ago, and to analyze the } \\
\text { associated risk factors. }\end{array}$ & $\begin{array}{l}\text { Multivar } \\
\text { iate } \\
\text { logistic } \\
\text { regressio } \\
\mathrm{n} \\
\text { analysis }\end{array}$ & $\begin{array}{l}1 . \\
\\
2 . \\
3 .\end{array}$ & $\begin{array}{l}\text { Results showed that } \\
57.5 \% \text { reported } \\
\text { symptoms of PTSD, } \\
58.7 \% \text { had } \\
\text { depression, and risk } \\
\text { factors of mental } \\
\text { health disorders are } \\
\text { age and exposure to } \\
\text { tornadoes. } \\
\text { The severity of PTSD } \\
\text { is higher in boys - } \\
\text { boys than in girls. } \\
\text { PTSD scores were } \\
\text { higher in children } \\
\text { aged } 15 \text { to } 17 \text { years } \\
\text { old than children } \\
\text { aged } 12 \text { to } 14 \text { years }\end{array}$ \\
\hline
\end{tabular}




\begin{tabular}{|c|c|c|c|c|c|}
\hline & & & & & $\begin{array}{l}\text { 4. The level of } \\
\text { depression is higher } \\
\text { in girls than in boys. } \\
\text { 5. Score average level } \\
\text { of depression was } \\
\text { significantly higher } \\
\text { in children aged } 15 \\
\text { to } 17 \text { years old than } \\
\text { children aged } 12 \text { to } \\
14 \text { years. } \\
\text { In conclusion, } \\
\text { students aged } 15-17 \\
\text { years at risk of } 1.87 \\
\text { to } 2.12 \text { times more } \\
\text { likely to experience } \\
\text { symptoms of PTSD } \\
\text { or depression than } \\
\text { students aged } 12 \text { to } \\
14 \text { years. }\end{array}$ \\
\hline $\begin{array}{l}1 \\
0\end{array}$ & $\begin{array}{l}\text { The impact } \\
\text { of the } \\
\text { Wenchuan } \\
\text { earthquak } \\
\text { e on early } \\
\text { puberty: a } \\
\text { natural } \\
\text { experimen } \\
t\end{array}$ & $\begin{array}{l}\text { Author: } \\
\text { Scaramut } \\
\text { ti et al.,/ } \\
2019\end{array}$ & $\begin{array}{l}\text { They assess the } \\
\text { relationship between the } \\
\text { impact of Wenchuan } \\
\text { earthquake-related and } \\
\text { early puberty, both in } \\
\text { boys and girls. }\end{array}$ & $\begin{array}{l}\text { Retrospe } \\
\text { ctive } \\
\text { cohort } \\
\text { study }\end{array}$ & $\begin{array}{l}\text { The results showed } \\
\text { 1. The impact of the } \\
\text { Wenchuan } \\
\text { earthquake increases } \\
\text { the risk of early } \\
\text { puberty in boys and } \\
\text { girls. } \\
\text { 2. Preschoolers are } \\
\text { more prone to } \\
\text { psychological } \\
\text { disorders compared }\end{array}$ \\
\hline
\end{tabular}




\begin{tabular}{|c|c|c|c|c|c|}
\hline & & & & & $\begin{array}{l}\text { with children of the } \\
\text { school. }\end{array}$ \\
\hline $\begin{array}{l}1 \\
1\end{array}$ & $\begin{array}{l}\text { The } \\
\text { Mental } \\
\text { Health } \\
\text { Impact of } \\
\text { Hurricane } \\
\text { Maria on } \\
\text { Puerto } \\
\text { Ricans in } \\
\text { Puerto } \\
\text { Rico and } \\
\text { Florida }\end{array}$ & $\begin{array}{l}\text { Carolina } \\
\text { et al., / } \\
2019\end{array}$ & $\begin{array}{l}\text { The purpose of this study } \\
\text { was to compare the } \\
\text { effects of Hurricane } \\
\text { Maria on and post- } \\
\text { traumatic stress disorder } \\
\text { (PTSD) among residents } \\
\text { of Puerto Rico who } \\
\text { moved to Florida after the } \\
\text { storm versus }\end{array}$ & $\begin{array}{l}\text { Quantita } \\
\text { tive }\end{array}$ & $\begin{array}{l}\text { The results of this } \\
\text { study are } \\
\text { The level of PTSD at } \\
\text { a higher population } \\
\text { of Florida is } 65.7 \% \text { ) } \\
\text { while the population } \\
\text { of Puerto Rico } \\
\text { (43.6\%) } \\
\text { People who live in } \\
\text { urban areas (Florida) } \\
\text { more significant risk } \\
\text { of PTSD than people } \\
\text { living in rural areas } \\
\text { (Puerto Rico }\end{array}$ \\
\hline $\begin{array}{l}1 \\
2\end{array}$ & $\begin{array}{l}\text { Post- } \\
\text { traumatic } \\
\text { stress } \\
\text { disorder } \\
\text { and its risk } \\
\text { factors in } \\
\text { Tibetan } \\
\text { bereaved } \\
\text { adolescent } \\
\text { s three } \\
\text { years after } \\
\text { the } 2010 \\
\text { Yushu } \\
\text { earthquak } \\
\text { e, a cross- } \\
\text { sectional }\end{array}$ & $\begin{array}{l}\text { Xiao et al., } \\
2019\end{array}$ & $\begin{array}{l}\text { 1. To determine the } \\
\text { incidence of post- } \\
\text { traumatic stress disorder } \\
\text { symptomatology (PTSD) } \\
\text { in adolescents grieving } \\
\text { Tibet three years after the } \\
\text { Yushu earthquake in } \\
\text { 2010, } \\
\text { 2. Identifying possibilities } \\
\text { and risk factors for PTSD }\end{array}$ & $\begin{array}{l}\text { Descript } \\
\text { ive } \\
\text { analysis } \\
\text { using } \\
\text { ANOVA } \\
\text { test. } \\
\text { Bivariate } \\
\text { logistic } \\
\text { regressio } \\
\mathrm{n} \\
\text { analysis } \\
\text { was } \\
\text { perform } \\
\text { ed to } \\
\text { assess } \\
\text { the }\end{array}$ & $\begin{array}{l}\text { The results show } \\
\text { that the Tibetan } \\
\text { teenagers who have } \\
\text { experience of PTSD } \\
\text { post-earthquake } \\
\text { mourning Yushu }\end{array}$ \\
\hline
\end{tabular}

IJSOC () 2020

http://ijsoc.goacademica.com 


\begin{tabular}{|c|c|c|c|c|c|}
\hline & $\begin{array}{l}\text { study in } \\
\text { China }\end{array}$ & & & $\begin{array}{l}\text { indepen } \\
\text { dent risk } \\
\text { factors } \\
\text { of } \\
\text { sympto } \\
\text { matolog } \\
\text { y PTSD. }\end{array}$ & \\
\hline 13 & $\begin{array}{l}\text { Post- } \\
\text { traumatic } \\
\text { stress } \\
\text { disorder } \\
\text { and coping } \\
\text { strategies } \\
\text { among } \\
\text { adult } \\
\text { survivors } \\
\text { of an } \\
\text { earthquak } \\
\text { e, Nepal } \\
\end{array}$ & $\begin{array}{l}\text { Adhikari } \\
\text { Baral } \\
\text { Ishwari } \\
\text { and } \\
\text { Bhagawa } \\
\text { ti/ } 2019\end{array}$ & $\begin{array}{l}\text { Investigate the } \\
\text { prevalence of post- } \\
\text { traumatic stress disorder } \\
\text { and the use of coping } \\
\text { strategies among adult } \\
\text { survivors of earthquakes. }\end{array}$ & $\begin{array}{l}\text { A cross- } \\
\text { sectional } \\
\text { descripti } \\
\text { ve }\end{array}$ & $\begin{array}{l}\text { - Earthquakes pose a } \\
\text { significant impact on } \\
\text { the mental health } \\
\text { problems of the } \\
\text { victims of the } \\
\text { earthquake } \\
\text { survivors. } \\
\text { Maladaptive coping } \\
\text { strategies lead to an } \\
\text { increase in PTSD in } \\
\text { victims. }\end{array}$ \\
\hline 14 & $\begin{array}{l}\text { Impact of } \\
\text { Major } \\
\text { Earthquak } \\
\text { es on } \\
\text { Parkinson' } \\
\text { s disease }\end{array}$ & $\begin{array}{l}\text { Ryoichi } \\
\text { kurisaki, } \\
\text { Hidetsug } \\
\text { u } \\
\text { Ueyama, } \\
\text { Yasushi } \\
\text { Maeda, } \\
\text { Tetsuro } \\
\text { Sakamoto } \\
\text { Nakahara } \\
\text { Keiichi, } \\
\text { Shunya } \\
\text { Nakane, }\end{array}$ & $\begin{array}{l}\text { This study investigates } \\
\text { the impact of the massive } \\
\text { earthquake in patients } \\
\text { with Parkinson's Disease. }\end{array}$ & $\begin{array}{l}\text { Quantita } \\
\text { tive } \\
\text { earth. }\end{array}$ & 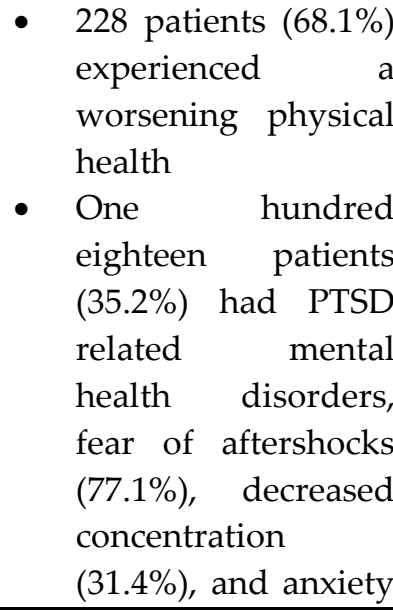 \\
\hline
\end{tabular}

IJSOC ๑ 2020

http://ijsoc.goacademica.com 


\begin{tabular}{|c|c|c|c|c|c|}
\hline & & $\begin{array}{l}\text { Satoshi } \\
\text { Yamashit } \\
\text { a, Yukio } \\
\text { Ando/ } \\
2019\end{array}$ & & & $\begin{array}{l}\text { associated concerns } \\
\text { the future }(32.3 \%) \text {. }\end{array}$ \\
\hline $\begin{array}{l}1 \\
5\end{array}$ & $\begin{array}{l}\text { Lessons } \\
\text { Learned } \\
\text { From the } \\
\text { Great East } \\
\text { Japan } \\
\text { Earthquak } \\
\text { e: Impact } \\
\text { on Child } \\
\text { and } \\
\text { Adolescen } \\
\text { t Health }\end{array}$ & $\begin{array}{l}\text { Kenji } \\
\text { Hayashi } \\
\text { and } \\
\text { Naoko } \\
\text { Tomita/ } \\
2016\end{array}$ & $\begin{array}{l}\text { I saw the impact of the } \\
\text { earthquake that occurred } \\
\text { in Japan, the eastern part } \\
\text { of the health of children } \\
\text { and adolescents. }\end{array}$ & $\begin{array}{l}\text { Qualitati } \\
\text { ve }\end{array}$ & $\begin{array}{l}\text { Tohoku Earthquake } \\
\text { caused } \\
\text { psychological effects } \\
\text { such as anxiety and } \\
\text { long-term social } \\
\text { impact. }\end{array}$ \\
\hline $\begin{array}{l}1 \\
6\end{array}$ & $\begin{array}{l}\text { Post- } \\
\text { traumatic } \\
\text { stress } \\
\text { disorder, } \\
\text { anxiety, } \\
\text { and } \\
\text { depression } \\
\text { symptoms } \\
\text { among } \\
\text { adolescent } \\
\text { earthquak } \\
\text { e Victims: } \\
\text { comorbidit } \\
\text { y and } \\
\text { associate }\end{array}$ & $\begin{array}{l}\text { Wanjie } \\
\text { Tang, Yi } \\
\text { Lu and } \\
\text { Xu } \\
\text { Jiuping/ } \\
2018\end{array}$ & $\begin{array}{l}\text { Our study aimed to } \\
\text { examine the prevalence } \\
\text { of psychiatric symptoms } \\
\text { and comorbidities and } \\
\text { their correlation with } \\
\text { sleep problems among } \\
\text { adolescents victims three } \\
\text { years after the earthquake } \\
\text { Ya'an, } 2013 \text {. }\end{array}$ & $\begin{array}{l}\text { Logistic } \\
\text { regressio } \\
n\end{array}$ & $\begin{array}{l}\text { Exposure to } \\
\text { earthquakes causing } \\
\text { some psychological } \\
\text { impact on children } \\
\text { and adolescents in } \\
\text { whom PTSD, } \\
\text { depression, anxiety, } \\
\text { feeling fear, } \\
\text { insomnia (difficulty } \\
\text { sleeping, } \\
\text { nightmares). }\end{array}$ \\
\hline
\end{tabular}




\begin{tabular}{|c|c|c|c|c|c|}
\hline & $\begin{array}{l}\text { sleep- } \\
\text { disturbing } \\
\text { factor }\end{array}$ & & & & \\
\hline $\begin{array}{l}1 \\
7\end{array}$ & $\begin{array}{l}\text { Psychosoci } \\
\text { al and } \\
\text { Mental } \\
\text { Health } \\
\text { Problems } \\
\text { of Older } \\
\text { People in } \\
\text { Nepal } \\
\text { Postearthq } \\
\text { uake }\end{array}$ & $\begin{array}{l}\text { P. } \\
\text { Ramesh } \\
\text { Adhikari, } \\
\text { Nawaraj } \\
\text { Upadhay } \\
\text { a, Sasmita } \\
\text { Paudel, } \\
\text { Ruja } \\
\text { Pokhrel, } \\
\text { Nagendr } \\
\text { a } \\
\text { Bhandari, } \\
\text { Laura } \\
\text { Cole, and } \\
\text { Suraj } \\
\text { Prasad } \\
\text { Koirala/ } \\
\text { 2019 }\end{array}$ & $\begin{array}{l}\text { To identify community } \\
\text { perceptions of } \\
\text { psychosocial and mental } \\
\text { health problems, parents } \\
\text { in a post-earthquake } \\
\text { situation in Nepal. }\end{array}$ & $\begin{array}{l}\text { Qualitati } \\
\text { ve }\end{array}$ & $\begin{array}{l}\text { Experienced health } \\
\text { problems such as } \\
\text { mood changes and } \\
\text { feelings, low self- } \\
\text { esteem, crying for no } \\
\text { reason this case is } \\
\text { associated with a } \\
\text { physical injury, } \\
\text { disability, family } \\
\text { conflict economic } \\
\text { problems, loss of } \\
\text { concentration, and } \\
\text { social isolation. }\end{array}$ \\
\hline $\begin{array}{l}1 \\
8\end{array}$ & $\begin{array}{l}\text { The } \\
\text { psychologi } \\
\text { cal impact } \\
\text { of a dual - } \\
\text { disaster } \\
\text { caused by } \\
\text { the } \\
\text { Earthquak } \\
\text { es and } \\
\text { radioactiv } \\
\text { e }\end{array}$ & $\begin{array}{l}\text { Tomihisa } \\
\text { niitsu, } \\
\text { City } \\
\text { Takoaka, } \\
\text { Saho } \\
\text { Uemura, } \\
\text { Akiko } \\
\text { Kono, } \\
\text { Akikho } \\
\text { Saito, } \\
\text { Norito }\end{array}$ & $\begin{array}{l}\text { This study investigated } \\
\text { the impact of the double } \\
\text { disaster (earthquake and } \\
\text { radioactive } \\
\text { contamination) on the } \\
\text { prevalence of } \\
\text { psychological distress in } \\
\text { the landlocked city in the } \\
\text { Tohoku region, Japan. }\end{array}$ & $\begin{array}{l}\text { Cross- } \\
\text { sectional }\end{array}$ & $\begin{array}{l}48 \% \text { of respondents } \\
\text { in Ichinoseki city } \\
\text { experienced } \\
\text { moderate } \\
\text { psychological } \\
\text { distress. }\end{array}$ \\
\hline
\end{tabular}




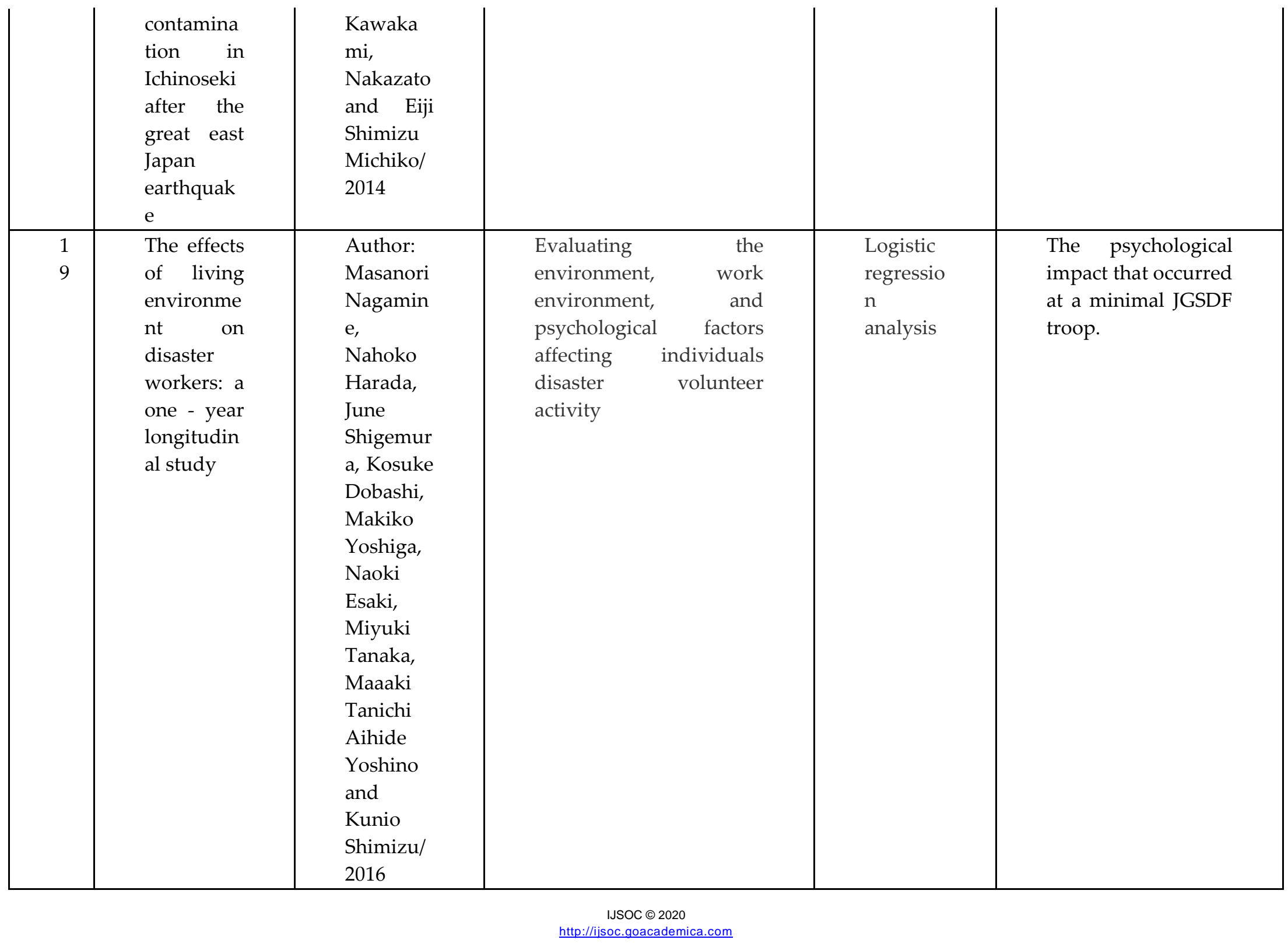




\begin{tabular}{|c|c|c|c|c|c|}
\hline $\begin{array}{l}2 \\
0\end{array}$ & $\begin{array}{l}\text { The Role of } \\
\text { Personalit } \\
\mathrm{y} \quad \text { and } \\
\text { Subjective } \\
\text { Exposure } \\
\text { Experience } \\
\text { in } \\
\text { Posttraum } \\
\text { atic Stress } \\
\text { Disorder } \\
\text { and } \\
\text { Depressio } \\
\mathrm{n} \text { among } \\
\text { Children } \\
\text { systems } \\
\text { Following } \\
\text { the } \\
\text { Wenchuan } \\
\text { Earthquak } \\
\text { e }\end{array}$ & $\begin{array}{l}\text { Xiancan } \\
\text { chen, } \\
\text { Jiajun xu, } \\
\text { Bin Li, Na } \\
\text { Li, Guo } \\
\text { Wanjun, } \\
\text { Shenng } \\
\text { Mao Ran, } \\
\text { June } \\
\text { Zhang } \\
\text { Yanchun } \\
\text { Yang and } \\
\text { Hu } \\
\text { Junme/ } \\
2017\end{array}$ & $\begin{array}{l}\text { Investigate the role of } \\
\text { personality traits and } \\
\text { subjective experience of } \\
\text { exposure in post- } \\
\text { traumatic stress disorder } \\
\text { and depressive } \\
\text { symptoms. }\end{array}$ & $\begin{array}{l}\text { Cross- } \\
\text { sectional }\end{array}$ & $\begin{array}{l}\text { The results of this } \\
\text { study indicate that } \\
\text { Symptoms of PTSD } \\
\text { and depression } \\
\text { commonly occur in } \\
\text { children after a } \\
\text { disaster. } \\
\text { Experience the child } \\
\text { feels unable to } \\
\text { escape from the } \\
\text { disaster experienced } \\
\text { extreme panic or fear } \\
\text { and was stuck for a } \\
\text { long time identified } \\
\text { affected by PTSD. }\end{array}$ \\
\hline
\end{tabular}




\section{Total Articles}

The total article obtained as many as 1,512. Filter results based on the title and inclusion criteria found 20 articles. After examining duplicate articles, I obtained 1009 articles for screening by checking the titles and abstracts. Four hundred fifty-eight articles do not correspond to the titles and abstracts, thus obtained 45 articles with full text for eligibility process is carried out. A flow diagram of the search and selection process is presented in (Figure 1). Finally, 20 articles have to review in this study consisted of 2 qualitative articles and 18 quantitative articles. As seen in Table 1, the natural disasters reviewed in this systematic review include earthquakes as much as 16 articles, a whirlwind two articles, one article about tsunamis, and one article about volcanic eruptions.

\section{Depression}

Four of the twenty research reports one of the mental health impacts of the disaster is the occurrence of depression. According to the research conducted by Cenat and Xusurvivors of the earthquake depressed $3,{ }^{3},{ }^{5}$. The signs that show depression by the quake victims, including; inability to feel pleasure and lose interest in doing daily activities $^{6}$. Several factors influence depression in victims of the earthquake that were gender and age. According to research conducted by Xu et al. (2018) shown that level of depression in girls is higher than boys, and children aged 15 to 17 years had a risk of 1.87 to 2.12 times more at risk of depression than children aged 12 to 14 years ${ }^{4}$. Furthermore, Dong et al. and Chen et al. stated one group that is easily depressed after experiencing the earthquake were children and pregnant women ${ }^{7}, 8$.

\section{Post-traumatic stress disorder (PTSD)}

Ten of the twenty articles reported the impact of natural disasters that victims experience post-traumatic stress disorder (PTSD). People who are victims of natural disasters to experience post-traumatic stress disorder (PTSD) $8,4,5,3$. Several factors cause PTSD in victims of natural disasters such as age, gender, location of residence, coping strategies used, unemployment status, education level, and experience of grieving ${ }^{9}{ }^{10}, 11,14$. In his research, Chen et al. add the experience the child feels unable to escape from the disaster and experiencing panic, extreme fear, and trapped in a long time to be a factor supporting the occurrence of PTSD ${ }^{15}$. Also, Baral and Bhagawati research 2019 and found that maladaptive coping strategies used by victims of the earthquake increased the incidence of PTSD in disaster victims ${ }^{11}$. Research conducted by Gissirardottri et al. and Carolina et al. found that communities living in areas affected by the storm more likely to have PTSD than people who live far away from the areas affected by the storm ${ }^{12},{ }^{13}$ Xiao et al. also explained that grieving teens who have rules of thumb risk for PTSD ${ }^{14}$. 


\section{Fear}

Three of the twenty articles reporting fear into one impact experienced by victims of natural disasters. Research conducted by Tang et al. found that victims experience fear ${ }^{16}$, Kurisaki et al. found that victims experience fear of aftershocks ${ }^{17}$. Besides, Cvetkovic also reported fears are the highest psychological impact experienced by the victims in the three areas studied, droughts, earthquakes, and epidemics incident is the most feared natural disaster by disaster victims ${ }^{18}$.

\section{Suicide}

One of twenty studies found the victims had suicidal thoughts. Chadda et al., in their study, found as many as $10 \%$ of victims of the earthquake had a desire to commit suicide ${ }^{19}$.

\section{Anxiety}

One of twenty studies found that the Tohoku earthquake's psychological impact is anxiety in the period long enough ${ }^{20}$.

\section{Other mental health problems}

Seven of the twenty articles reporting natural disasters lead to mental health problems. Research conducted by Edwards et al. found that drought causes mental health problems in people who work in agriculture are more significant than those who are not working in the field of agriculture ${ }^{21}$. In his research, Lieber also found children who have trauma in the past to be at risk of mental health problems on ${ }^{22}$. Research conducted by niitsu et al. on earthquake victims reported that the average earthquake victims experience psychological distress ${ }^{23}$. Further research conducted by Ramesh et al. found that mental health problems experienced by the victims of such disasters, mood changes, low self-esteem, and crying for no reason can be attributed to physical injuries suffered, disability, conflict, and family issues and economic issues ${ }^{24}$. Research conducted by. Baral and Bhagawati find an earthquake cause a significant impact on the mental health problems of survivors ${ }^{11}$. But research conducted by Nagamine et al. (2016) contradicts the previous research. Nagamine finds the psychological impact experienced by a very small JGSDF troops ${ }^{25}$. The disaster provides trauma for the victim. This is because of the disaster and without warning, causing widespread destruction, death, injury, loss of property or loss of shelter and economic losse ${ }^{26}$ Exposure to traumatic events causing them to be able to manage the problems experienced so can cause stress on its victims. Traumatic stress usually caused by a severe injury that is felt from the death of or threat to the physical integrity of self or others that can cause its victims to experience psychological disorders. Stress experienced by the victim may lead to the condition of post-traumatic disorder (PTSD) experienced a few months or years after the occurrence of natural 
disasters. People with PTSD usually show symptoms such as repeating the traumatic event, avoidance behavior, and nightmares. The psychological condition of victims with feelings of mourning in the long term can fall on the condition of depression caused people to feel the despair of all the labor of any that do not bring change to their lives. Individuals who are depressed would be interested in the things that he liked before experiencing a traumatic event. Individuals also develop true feelings, feelings of guilt, blame themselves and feel that the events that happened were his fault. This happens because the victim cannot manage the problems that happened; thus, several victims of natural disasters have feelings of despair and do not want to continue her life and have the desire to commit suicide because of the heavy burden borne. Psychological problems experienced by victims of natural disasters is closely associated with coping strategies. Use adaptive coping strategies that can help reduce psychological problems and direct people towards adaptive behaviors.

\section{CONCLUSION}

The disaster not only affects the physical condition of the victims and the environment but also affects the psychological conditions such as depression earthquake victims Post-traumatic stress disorder (PTSD), fears, suicide, and other mental health problems. If the psychological problems do not get adequate treatment, they can fall victim to the condition of a more serious mental disorder. 


\section{REFRENCES}

1. Adhikari Baral I, Bhagawati KC. Post-traumatic stress disorder and coping strategies among adult survivors of the earthquake, Nepal. BMC Psychiatry. 2019;19(1):1-8. DOI:10.1186/s12888-019-2090-y

2. Adhikari Ramesh P, Upadhaya N, Paudel S, et al. Psychosocial and Mental Health Problems of Older People in Post-earthquake Nepal. J Aging Health. 2018;30(6):945964. DOI:10.1177/0898264317702056

3. Cénat JM, Derivois D. Assessment of prevalence and determinants of posttraumatic stress disorder and depression symptoms in adult survivors of the earthquake in Haiti after 30 months. J Affect Disord. 2014;159:111-117. DOI:10.1016/j.jad.2014.02.025

4. Chadda RK, Malhotra A, Kaw N, Singh J, Sethi H. Mental health problems following the 2005 earthquake in Kashmir: Findings of community-run clinics. Prehosp Disaster Med. 2007;22(6):541-545. DOI:10.1017/S1049023X00005409

5. Chadda RK, Malhotra A, Kaw N, Singh J, Sethi H. Mental health problems following the 2005 earthquake in Kashmir: Findings of community-run clinics. Prehosp Disaster Med. 2007;22(6):541-545. DOI:10.1017/S1049023X00005409

6. Cheng Y, Li X, Lou C, et al. The association between social support and mental health among vulnerable adolescents in five cities: Findings from the study of adolescents' well-being in vulnerable environments. J Adolesc Heal. 2014;55(6): S31S38. DOI:10.1016/j.jadohealth.2014.08.020

7. Cvetković VM, Öcal A, Ivanov A. Young adults' fear of disasters: A case study of residents from Turkey, Serbia, and Macedonia. Int J Disaster Risk Reduct. 2019;35(February). DOI:10.1016/j.ijdrr.2019.101095

8. Dong X, Qu Z, Liu F, et al. Depression and its risk factors among pregnant women in the 2008 Sichuan earthquake area and non-earthquake struck an area in China. J Affect Disord. 2013;151(2):566-572. DOI:10.1016/j.jad.2013.06.048

9. Edwards B, Gray M, Hunter B. The Impact of Drought on Mental Health in Rural and Regional Australia. Soc Indic Res. 2015;121(1):177-194. DOI:10.1007/s11205-0140638-2

10. Gissurardóttir ÓS, Hlodversdóttir H, Thordardóttir EB, Pétursdóttir G, Hauksdóttir A. Mental health effects following the eruption in Eyjafjallajökull volcano in Iceland: A population-based study. Scand J Public Health. 2019;47(2):251259. DOI:10.1177/1403494817751327

11. Hayashi K, Tomita N. Lessons learned from the Great East Japan earthquake: Impact on child and adolescent health. Asia-Pacific J Public Heal. 2012;24(4):681-688. DOI:10.1177/1010539512453255

12. Kurisaki R, Ueyama H, Maeda Y, et al. Impact of major earthquakes on Parkinson's 
disease. J Clin Neurosci. 2019;61:130-135. DOI:10.1016/j.jocn.2018.10.107

13. Kurisaki R, Ueyama H, Maeda Y, et al. Impact of major earthquakes on Parkinson's disease. J Clin Neurosci. 2019;61:130-135. DOI:10.1016/j.jocn.2018.10.107

14. Lian Q, Zuo X, Mao Y, et al. The impact of the Wenchuan earthquake on early puberty: A natural experiment. PeerJ. 2018;2018(6):1-12. DOI:10.7717/peerj.5085

15. Lieber M. Assessing the mental health impact of the 2011 great japan earthquake, tsunami, and radiation disaster on elementary and middle school children in the fukushima prefecture of japan. PLoS One. 2017;12(1):1-15. DOI:10.1371/journal.pone.0170402

16. Nagamine M, Harada N, Shigemura J, et al. The effects of living environment on disaster workers: A one-year longitudinal study. BMC Psychiatry. 2016;16(1). DOI:10.1186/s12888-016-1058-4

17. Neria Y, Nandi A, Galea S. Post-traumatic stress disorder following disasters: A systematic review. Psychol Med. 2008; 38(4): 467-480. DOI:10.1017/S0033291707001353

18. Niitsu T, Takaoka K, Uemura S, et al. The psychological impact of a dual-disaster caused by earthquakes and radioactive contamination in Ichinoseki after the Great East Japan Earthquake. BMC Res Notes. 2014;7(1):1-7. DOI:10.1186/1756-0500-7-307

19. Scaramutti Carolina, Salas-Wright CP, Vos SR, Schwartz SJ. The Mental Health Impact of Hurricane Maria on Puerto Ricans in Puerto Rico and Florida. Disaster Med Public Health Prep. 2019;13(1):24-27. DOI:10.1017/dmp.2018.151

20. Supari dkk. Pedoman Teknis Penanggulangan Krisis Kesehatan Akibat Bencana.

21. Tang W, Lu Y, Xu J. Post-traumatic stress disorder, anxiety, and depression symptoms among adolescent earthquake victims: comorbidity and associated sleep-disturbing factors. Soc Psychiatry Psychiatr Epidemiol. 2018;53(11):1241-1251. DOI:10.1007/s00127-018-1576-0

22. Tang W, Lu Y, Xu J. Post-traumatic stress disorder, anxiety, and depression symptoms among adolescent earthquake victims: comorbidity and associated sleep-disturbing factors. Soc Psychiatry Psychiatr Epidemiol. 2018;53(11):1241-1251. DOI:10.1007/s00127-018-1576-0

23. Ueda I, Sakuma A, Takahashi Y, et al. criticism by community people and poor workplace communication as risk factors for the mental health of local welfare workers after the Great East Japan Earthquake: A cross-sectional study. PLoS One. 2017;12(11):1-15. DOI:10.1371/journal.pone.0185930

24. Xiao Y, Liu D, Liu K, Jiang X. Post-traumatic stress disorder and its risk factors in bereaved Tibetan adolescents three years after the 2010 Yushu earthquake, a crosssectional study in China. Arch Psychiatr Nurs. 2019;33(2):149-154. DOI:10.1016/j.apnu.2018.11.010 
25. Xiao Y, Liu D, Liu K, Jiang X. Post-traumatic stress disorder and its risk factors in bereaved Tibetan adolescents three years after the 2010 Yushu earthquake, a crosssectional study in China. Arch Psychiatr Nurs. 2019;33(2):149-154. DOI:10.1016/j.apnu.2018.11.010

26. Xu W, Yuan G, Liu Z, Zhou Y, An Y. Prevalence and predictors of PTSD and depression among adolescent victims of the Summer 2016 tornado in Yancheng City. Arch Psychiatr Nurs. 2018;32(5):777-781. DOI:10.1016/j.apnu.2018.04.010 